\title{
Embryonic lethality in mice homozygous for a targeted disruption of the $\mathrm{N}-m y c$
} gene

\author{
Jean Charron,, ${ }^{1,2}$ Barbara A. Malynn, ${ }^{1,3}$ Peter Fisher, ${ }^{1,4}$ Valerie Stewart, ${ }^{1,3}$ Lucie Jeannotte, ${ }^{2,5}$ \\ Stephen P. Goff, ${ }^{1}$ Elizabeth J. Robertson, ${ }^{5}$ and Frederick W. Alt ${ }^{1,3}$ \\ ${ }^{1}$ The Howard Hughes Medical Institute and Departments of Biochemistry and Molecular Biophysics, and Microbiology, \\ College of Physicians and Surgeons, Columbia University, New York, New York 10032 USA; ${ }^{2}$ Centre de Recherche \\ en cancerologie de L'Universite Laval, Hotel-Dieu de Quebec, Quebec, Canada, G1R 2J6; ${ }^{3}$ The Howard Hughes Medical \\ Institute, The Children's Hospital, Boston, Massachusetts 02115 USA; ${ }^{4}$ Department of Pathology; ${ }^{5}$ Department of Genetics \\ and Development, College of Physicians and Surgeons, Columbia University, New York, New York 10032 USA
}

The $\mathbf{N}$-myc gene encodes a putative transcription factor that is thought to function in the regulation of gene expression during cell differentiation and/or growth. To examine the role of $\mathrm{N}$-myc during development, we have used targeted mutagenesis in embryonic stem cells to produce a mouse line that carries an $\mathbf{N}$-myc null allele. Mice homozygous for the mutation died between 10.5 and 12.5 days of gestation. Histological analysis of mutant embryos revealed that organs and tissues expected at these stages of development were present. However, multiple defects were observed, primarily in tissues and organs that normally express N-myc. In particular, mutant hearts were underdeveloped, often retaining the S-shape more typical of 9-day-old embryos. In addition, cranial and spinal ganglia were reduced in size and/or cellularity. Most of the noted defects were more consistent with a role of $\mathrm{N}$-myc in proliferation of precursor populations than with a block in differentiation per se, at least at these early stages. These results demonstrate that $\mathrm{N}$-myc plays an essential role during development and clearly confirm that $\mathrm{N}$-myc has a physiological function that is distinct from that of the other myc-family genes.

[Key Words: Gene disruption; N-myc; developmental retardation]

Received September 11, 1992; accepted October 9, 1992.

The $\mathrm{N}$-myc gene is a member of a family of nuclear proto-oncogenes that includes three well-characterized members, c-myc, N-myc, and L-myc (Alt et al. 1986). These genes encode related but distinct nuclear phosphoproteins that can contribute to tumorigenesis both in vitro and in vivo. The three myc-family genes have distinct expression patterns in normal development, and changes in their expression have been correlated with the response of cultured cells to differentiation agents and mitogenic stimuli. The activation pattern of these genes in spontaneously arising tumors also appears to partially reflect their specific expression patterns during normal development. On the basis of such findings, the myc gene products are thought to function in the regulation of gene expression in the context of cell growth and differentiation (Zimmerman and Alt 1990), but their precise function remains to be determined.

Various findings have led to the suggestion that myc proteins may function to regulate transcription, DNA replication, or both (Lüscher and Eisenman 1990). In particular, regions conserved among myc proteins include DNA-protein or protein-protein interaction motifs that have been found in a number of other DNA-binding, transcriptional regulatory, and cell-lineage determination proteins (Villares and Cabrera 1987; Caudy et al. 1988; Thisse et al. 1988; Olso 1990). This speculation was supported further by the fact that all three proteins have been found to specifically bind a common DNA sequence (Blackwell et al. 1990; Halazonetis and Kandil 1991; Kerkhoff et al. 1991; Prendergast and Ziff 1991, 1992; Alex et al. 1992; Ma et al. 1992) and that such binding is facilitated by heterodimeric association with the Max protein (Blackwood and Eisenman 1991; Prendergast et al. 1991; Ma et al. 1992). The observation that these three proteins appear to bind preferentially to the same target sequence and in association with the same partner protein suggests that their activities may overlap significantly (Ma et al. 1992).

A function for $\mathrm{N}$-myc in normal cell growth has been suggested by observations that overexpression of $\mathrm{N}-m y c$ in growth factor-deprived quiescent fibroblasts can induce DNA synthesis (Cavalieri and Goldfarb 1988) and that $\mathrm{N}-m y c$ is induced in pre-B cells following exposure to the mitogenic factor interleukin-7 (IL-7) (Morrow et al. 1992). Furthermore, the N-myc protein was demonstrated to bind in vitro to the retinoblastoma $(\mathrm{Rb})$ gene 
product, which has been purported to have a role in cell cycle regulation (Rustgi et al. 1991; Wagner and Green 1991). In this regard, it has been proposed that $\mathrm{Rb}$ may modulate transcription during the cell cycle by modifying the activity of transcriptional factors such as E2F (Wagner and Green 1991; Weintraub et al. 1992).

During murine embryogenesis, the $\mathrm{N}-\mathrm{myc}$ gene has a very restricted pattern of expression. The earliest stage at which $\mathrm{N}$-myc expression has been documented is that of gastrulation. At this stage, $\mathrm{N}-\mathrm{myc}$ transcripts are found at their highest levels in the expanding primitive streak and embryonic mesoderm (Downs et al. 1989). Once somitogenesis and neurulation proceed, the highest levels of $\mathrm{N}-m y c$ expression are detected in the central nervous system (CNS) in the cranial and spinal ganglia and within other structures of neural crest origin, such as the mesenchyme of the mandibular and maxillary processes (Kato et al. 1991). During early organogenesis, a marked restriction in the spatial distribution of $\mathrm{N}-m y c$ expression is observed. The primitive nephric tubules, the sclerotome, the myocardium of the cardiac ventricles, and the digestive tract express abundant levels of $\mathrm{N}-m y c$ (Kato et al. 1991). Later, N-myc transcripts are detected in the lung, kidney, gut, and stomach epithelium $(\mathrm{Mu}-$ grauer et al. 1988; Hirning et al. 1991). In adult mice, $\mathrm{N}$-myc expression tends to be low or undetectable in most differentiated tissues, although expression is found in lymphoid differentiation organs where the gene continues to be expressed in precursor lymphocytes (Zimmerman and Alt 1990; Morrow et al. 1992). Thus, N-myc expression appears to be confined to cells that represent early differentiation stages in tissues derived from different embryonic germ cell layers, suggesting that N-myc may play an important generalized function in the differentiation of tissues and/or organs, perhaps to promote the self-renewal of precursor cells and/or to preclude their terminal differentiation.

To directly test for an essential function for N-myc in mammalian development, we have used gene-targeted mutagenesis in embryonic stem (ES) cells to generate a line of mice that carry a null mutation of the N-myc gene. Mice homozygous for this mutation die during embryonic development and show defects in the formation of a number of different tissues and organs.

\section{Results}

\section{Inactivation of the $\mathrm{N}$-myc gene in mice}

Previously, we have described the generation of ES cell lines in which a portion of the second exon of the N-myc gene was replaced with a neor gene (Charron et al. 1990). The mutant $\mathrm{N}$-myc allele generated by this approach lacks most of the second exon of N-myc and is not likely to produce a partial $\mathrm{N}-m y c$ protein because the neo gene fused after the second codon of the N-myc gene is terminated by stop codons in all three reading frames. Moreover, no ATG initiation codon is present in the $\mathrm{N}-m y c$ reading frame of the fusion transcript downstream of the neo gene. Two ES cell clones (CCE-P-7.3 and CCE-P-7.12) were injected into C57BL/6 blastocysts, which were used to generate somatic chimeras. Male chimeras were bred to check for germ-line contribution of the ES cells by screening for the presence of agouti offspring following mating to non-agouti (black) females. Germ-line chimeras were obtained from CCE-P-7.12. As expected, $50 \%$ of these offspring carried the mutated $\mathrm{N}-\mathrm{myc}$ allele, as evidenced by Southern blotting procedures. The $\mathrm{N}-\mathrm{myc}^{+1-}$ mice were not overtly abnormal compared with their wild-type littermates. In addition, $\mathrm{N}-\mathrm{myc}^{+/-}$animals of both sexes were fertile. The $\mathrm{N}-\mathrm{myc}^{+/-}$mice were bred to MF1 mice to expand the pool of mice carrying the mutated $\mathrm{N}-\mathrm{myc}$ allele.

\section{Homozygous $\mathrm{N}$-myc mutant animals die in utero}

To investigate the effect of loss of $\mathrm{N}-m y c$ function, $\mathrm{N}-\mathrm{myc}^{+1-}$ mice were intercrossed. Genotypes of the resulting offspring were determined at 3-4 weeks of age by Southern blot analysis of tail DNA using a $5^{\prime} \mathrm{N}-m y c$ EcoRI-BamHI probe (Charron et al. 1990). From a total of 191 progeny analyzed, no mice homozygous for the $\mathrm{N}-\mathrm{myc}^{-}$mutation were found, clearly indicating that the mutation results in embryonic lethality (Table 1). These findings are in accord with those of a recent preliminary characterization of a separate $\mathrm{N}-m y c$ null $\mathrm{mu}-$ tant line (Sewal et al. 1991). To determine the time of death more precisely, $\mathrm{N}-\mathrm{myc}^{+1-}$ animals were intercrossed, and pregnant females were sacrificed at different times of gestation. (The day at which the vaginal plug was found is designated $0.5 \mathrm{dpc}$ ). The embryos were dissected out of the visceral yolk sac, and their genotype was determined by Southern blot analysis of DNA isolated from the corresponding yolk sac (Fig. 1; only 9.5 $\mathrm{dpc}$ and $11.5 \mathrm{dpc}$ are shown in panels $\mathrm{A}$ and $\mathrm{B}$, respectively). As a control, we also analyzed DNA isolated from maternal tissues at the time of the dissection; in this assay, the wild-type gene is visualized as a $7.7-\mathrm{kb}$ band and the mutant allele as an $8.4-\mathrm{kb}$ band (Fig. 1,

Table 1. Viability of $N$-myc ${ }^{-} / N$-myc ${ }^{-}$embryos

\begin{tabular}{lccccc}
\hline & & & \multicolumn{3}{c}{$\begin{array}{c}\text { Genotype of } \\
\text { live embryos }\end{array}$} \\
\cline { 4 - 6 } Age $^{\mathrm{a}}$ & $\begin{array}{l}\text { Number } \\
\text { of litters }\end{array}$ & $\begin{array}{l}\text { Number } \\
\text { of pups }\end{array}$ & $+1+$ & $+1-$ & $-1-$ \\
\hline E9.5 & 7 & 50 & 10 & 27 & 13 \\
E10.5 & 14 & 95 & 21 & 46 & 28 \\
E11.5 & 13 & 93 & 26 & 50 & $6^{\mathrm{b}}$ \\
E12.5 & 9 & 51 & 18 & 25 & $0^{\text {c }}$ \\
E13.5 & 1 & 4 & 3 & 1 & 0 \\
W3-4 & 33 & 191 & 53 & 138 & 0
\end{tabular}

${ }^{\mathrm{a} E 9.5, ~ E 10.5, ~ E 11.5, ~ a n d ~ E 12.5 ~ r e p r e s e n t ~ d a y s ~ 9.5, ~ 10.5, ~ 11.5, ~ a n d ~}$ 12.5 of gestation, respectively; W3-4 represents a range in ages of the pups in weeks after birth.

'In addition, 11 dead $\mathrm{N}-\mathrm{myc}^{-} / \mathrm{N}-\mathrm{myc}^{-}$embryos were genotyped during the process of resorption.

'In addition, 8 dead $\mathrm{N}-\mathrm{myc}^{-} / \mathrm{N}-\mathrm{myc}^{-}$embryos were genotyped during the process of resorption. 
A

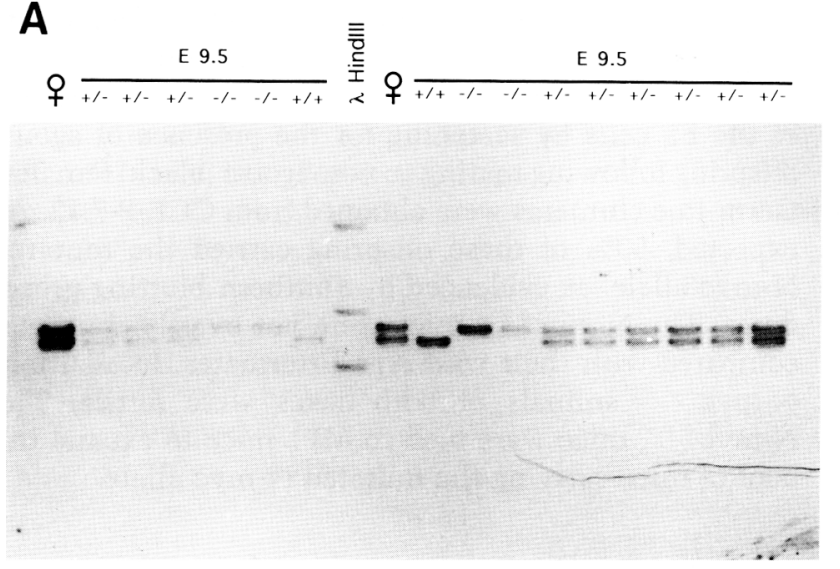

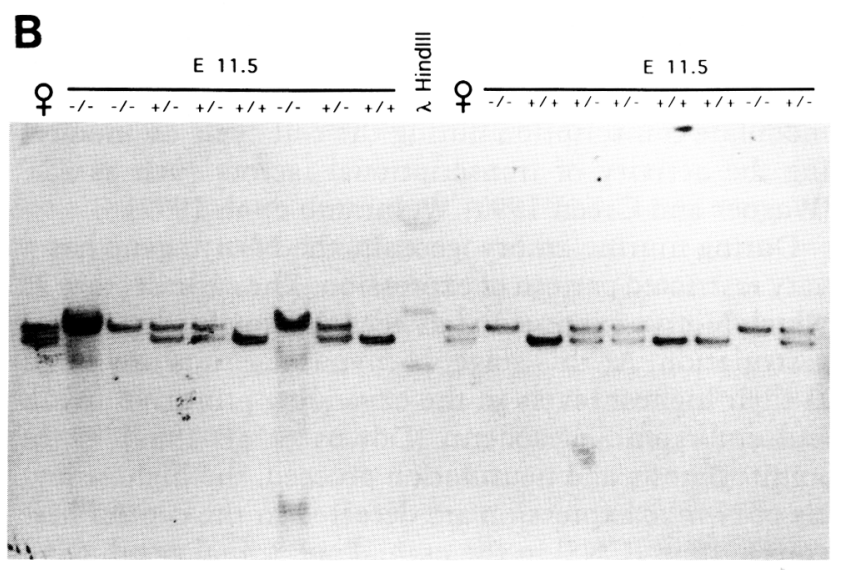

Figure 1. Southern analysis of offspring from heterozygous crosses. Yolk sac DNAs from 9.5-dpc (E9.5, A) and 11.5-dpc (E11.5, B) embryos derived from $\mathrm{N}-\mathrm{myc}^{+/-}$heterozygote crosses were digested with EcoRI, Southern blotted, and probed with a $5^{\prime} \mathrm{N}-\mathrm{myc}$ EcoRI-BamHI probe (Charron et al. 1990). Lanes $\&$ show tail DNA isolated from the mother, and wild-type ( + ; lower bands) and disrupted N-myc alleles (-; upper bands). The genotype of each embryo is indicated at the top of each lane.

$\mathrm{A}, \mathrm{B})$. These studies demonstrated that at $9.5 \mathrm{dpc}$ and 10.5 $\mathrm{dpc}$, the ratio of wild-type, $\mathrm{N}-\mathrm{myc}^{+/-}$and $\mathrm{N}-\mathrm{myc}^{-1-}$ embryos is $1: 2: 1$ (Fig. 1; Table 1). However, at 11.5 dpc, 11 of the $17 \mathrm{~N}-\mathrm{myc}^{-} / \mathrm{N}-\mathrm{myc}^{-1-}$ embryos identified were moribund or dead and in the process of resorption. Of note, a variable amount of DNA degradation was observed in some of these samples (Fig. 1B, lanes 2,7). At $12.5 \mathrm{dpc}$, fewer homozygous mutant embryos were found and they were all in the process of being resorbed. This analysis indicates that absence of functional N-myc expression results in embryonic lethality between 10.5 $\mathrm{dpc}$ and $12.5 \mathrm{dpc}$.

\section{Expression of normal and mutated $N$-myc alleles}

A recent report described an $\mathrm{N}$-myc mutation that was designed to disrupt gene function but was found to be incomplete owing to an unexpected integration of the construct that permitted expression of variable levels of normal transcripts (Bernelot-Moens et al. 1992). Restriction mapping analyses of the targeted $\mathrm{N}$-myc allele in CCE-P-7.12 confirmed that we had achieved the intended replacement mutation (data not shown). To confirm this finding in mutant animals, we used Northern blotting procedures to assay for production of wild-type and mutated $\mathrm{N}-m y c$ transcripts in $\mathrm{N}-\mathrm{myc}^{+/+}, \mathrm{N}-\mathrm{myc}^{+/-}$, and $\mathrm{N}-\mathrm{myc}^{-1-}$ embryos at $10.5 \mathrm{dpc}$. RNA samples were assayed for hybridization to an $\mathrm{N}-m y c$ exon 3 probe that detects transcripts from both the normal (expected size, $2.9 \mathrm{~kb}$ ) and mutated (expected size, $3.6 \mathrm{~kb}$ ) alleles (Charron et al. 1990). These analyses demonstrated that only the 3.6-kb N-myc/neo fusion transcripts were present in $\mathrm{N}-\mathrm{myc}^{-1-}$ embryos, confirming that the mutation eliminates expression of normal N-myc mRNA (Fig. 2, top). To verify this interpretation we also assayed these RNAs for hybridization to a second probe derived from N-myc exon 2 sequences that were deleted in the mutated allele; as expected, this probe detects normal $2.9-\mathrm{kb}$ tran- scripts in RNA from $\mathrm{N}-\mathrm{myc}^{+/+}$or $\mathrm{N}-\mathrm{myc}^{+/-}$embryos but detects no transcripts in the RNA samples from $\mathrm{N}-\mathrm{myc}^{-1-}$ embryos (Fig. 2, middle).

Phenotype of the $\mathrm{N}$-myc $\mathrm{m}^{-1-}$ mice

At all days examined, $\mathrm{N}-\mathrm{myc}^{-1-}$ embryos were often, but not always, substantially reduced in size compared with their $\mathrm{N}-\mathrm{myc}^{+1-}$ or $\mathrm{N}-\mathrm{myc}^{+1+}$ littermates/data not shown). Furthermore, at $9.5-11.5 \mathrm{dpc}$, we observed 3 homozygous mutant embryos of 12 with a profoundly reduced cellularity throughout the embryo (based on microscopic inspection of tissue sections), but none of these embryos showed any sign of necrosis. The reduction in size also was reflected by the amount of RNA that could be extracted from the N-myc ${ }^{-1-}$ mutant embryos compared with those of wild-type and heterozygous animals. On a per embryo basis, we could extract only about half the amount of RNA from a 10.5-dpc homozygous mutant embryo $(58 \pm 3 \mu g ; n=5)$ as we could from a corresponding wild-type $(112 \pm 4 \mu \mathrm{g}$; $n=4)$ or a heterozygous $(128 \pm 3 \mu \mathrm{g} ; n=4)$ embryo. Assuming that the amount of extractable RNA correlates with cell number, this result is consistent with the visual indications that the homozygous mutant embryos had fewer cells than their wild-type or heterozygous littermates. Taken together, these results suggest that the homozygous $\mathrm{N}-m y c$ mutation may interfere with cell proliferation.

To determine whether this apparent difference in size and/or cellularity was the result of a generalized developmental retardation of the homozygous mutant embryos, we determined their developmental stage compared with that of control littermates by counting the number of somite pairs. At $9.5 \mathrm{dpc}$, we found $26 \pm 2$ somite pairs $(n=3), 27 \pm 1$ somite pairs $(n=8)$ and $25 \pm 2$ somite pairs $(n=8)$ for the $\mathrm{N}-\mathrm{myc}^{+1+}, \mathrm{N}-\mathrm{myc}^{+1-}$, and $\mathrm{N}-\mathrm{myc}^{-1-}$ embryos, respectively. At $10.5 \mathrm{dpc}$, we found 


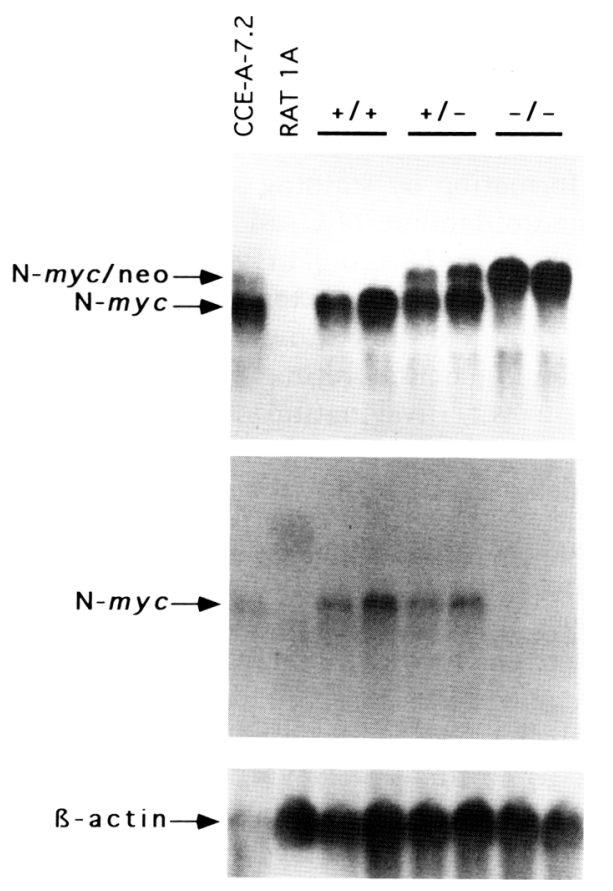

Figure 2. Expression of the N-myc gene in 10.5-dpc N-myc wild-type, heterozygous, and homozygous mutant embryos. Total RNA (15 $\mu \mathrm{g}$ ) was isolated from whole 10.5-dpc embryos, fractionated by electrophoresis through a formaldehyde-agarose gel, transferred to Hybond membrane, and assayed for hybridization to ${ }^{32} \mathrm{P}$-labeled probes. Two individual wild-type $(+/+1$, heterozgous $(+1-1$, and homozygous mutant $(-1-)$ embryos were analyzed. Duplicate blots were hybridized to $\mathrm{N}-m y c$ third exon (top) and $\mathrm{N}-m y c$ second exon (middle) probes. Blots were subsequently hybridized to a $\beta$-actin probe (bottom) to control for the relative quantity of mRNA in each lane. CCE-A-7.2 is an ES cell line in which one allele of N-myc was targeted by the same strategy used to derive the mutant mouse strain. RAT 1A is a fibroblast cell line as a negative control.

$35 \pm 3$ somite pairs $(n=3), 35 \pm 2$ somite pairs $(n=10)$, and $33 \pm 3$ somite pairs $(n=8)$ for $\mathrm{N}-$ myc $^{+/+}$, $\mathrm{N}-\mathrm{myc}^{+1-}$, and $\mathrm{N}-\mathrm{myc}^{-1-}$ embryos, respectively. Thus, based on this criterion, the $\mathrm{N}-\mathrm{myc}^{-1-}$ embryos were at approximately the same stage of development as their wild-type and heterozygous littermates.

To determine whether the retardation in the growth of the N-myc ${ }^{-1-}$ embryos was the result of abnormal placentation, histological sections of placentas were examined by hematoxylin and eosin staining. No differences were observed (data not shown). Recently, embryonic lethality in mutant mice that lack a functional c-myb product was shown to result from a defect in erythropoiesis (Mucenski et al. 1991). However, erythropoiesis in the $\mathrm{N}-\mathrm{myc}^{-1-}$ embryos appeared normal based on a histological survey. In addition, we found that cells recovered from 9.5-dpc N-myc ${ }^{-1-}$ yolk sacs could differentiate into red blood cells in an in vitro culture system (Wong et al. 1986a,b; data not shown). Therefore, the embryonic lethality in $\mathrm{N}-\mathrm{myc}^{-1-}$ mice does not appear to result from a deficiency in erythropoiesis, although we cannot preclude a role for $\mathrm{N}-m y c$ in erythropoiesis later in development.

To define more precisely the phenotype of $\mathrm{N}-\mathrm{myc}^{-/-}$ mice, we performed an extensive histological analysis of sections of 9.5-, 10.5-, and 11.5-dpc embryos. These studies revealed that all of the structures and organs were present in $\mathrm{N}-\mathrm{myc}^{-1-}$ embryos. However, at all stages examined, the development of certain homozygous mutant organs appeared retarded relative to that of control littermates. The most striking differences will be discussed in detail in the following paragraphs.

Heart The organ most strikingly affected by the $\mathrm{N}-\mathrm{myc}^{-1-}$ mutation is the heart. At $9.5,10.5$, and 11.5 $\mathrm{dpc}$, the heart is one of the most differentiated organs. At this time in development, $\mathrm{N}$-myc expression is restricted to the myocardium. Comparison of multiple transverse histological sections of different wild-type and mutant embryos at the level of the heart revealed dramatic differences (Fig. 3; representative sections are shown). Differences between wild-type and mutant hearts were noted as early as $9.5 \mathrm{dpc}$; in contrast to the wild-type hearts, the ventricular region of 9.5 -dpc homozygous mutant embryos has not yet divided into chambers, and the trabeculation of the ventricle is reduced (Fig. 3). At 10.5 and $11.5 \mathrm{dpc}$, even more dramatic differences were noted. In the wild-type embryos, the myocardium is well developed and it is possible to distinguish the atria, the ventricles, atrioventricular canal, interatria septum, interventricular septum, and the trabeculae carneae (Fig. 3; representative sections are shown). However, the hearts of all the 10.5-dpc $(n=4)$ and 11.5-dpc $(n=3)$ mutant embryos analyzed appeared substantially underdeveloped compared with the wild-type embryos (Fig. 3). In four of the 10.5-dpc and one of the 11.5-dpc mutant embryos, we could identify the area within the heart tissue that should generate the atria and the ventricles; however, these hearts retained the S-shape more typical of embryonic day 9. In addition, the endocardium, which normally undergoes a regionally restricted epithelialmesenchymal transformation to generate the anlagen of valvular and septal tissues (Zak 1984), is still present in the 10.5- and 11.5-dpc mutant hearts. In the other two 11.5-dpc mutant embryos, the atria and ventricular chambers of the heart were present and formation of the interventricular septums was initiated. However, trabeculation of the ventricles was reduced, suggesting that heart development was less advanced (data not shown).

In two mutant embryos (one at $10.5 \mathrm{dpc}$ and the other at $11.5 \mathrm{dpc}$ ), the pericardium appeared normal but its cavity was almost empty owing to the underdeveloped heart (Fig. 3). In two 11.5-dpc mutant embryos, we also observed the enlargement or dilatation of the anterior cardinal vein (Fig. 3). Such changes were never observed in wild-type or heterozygous embryos.

CNS The N-myc gene is highly expressed in the CNS during development. Therefore, we examined multiple sections of 9.5- through 11.5-dpc embryos to determine whether the absence of $\mathrm{N}-m y c$ perturbed neural development. In the CNS, the expression of the N-myc gene is 


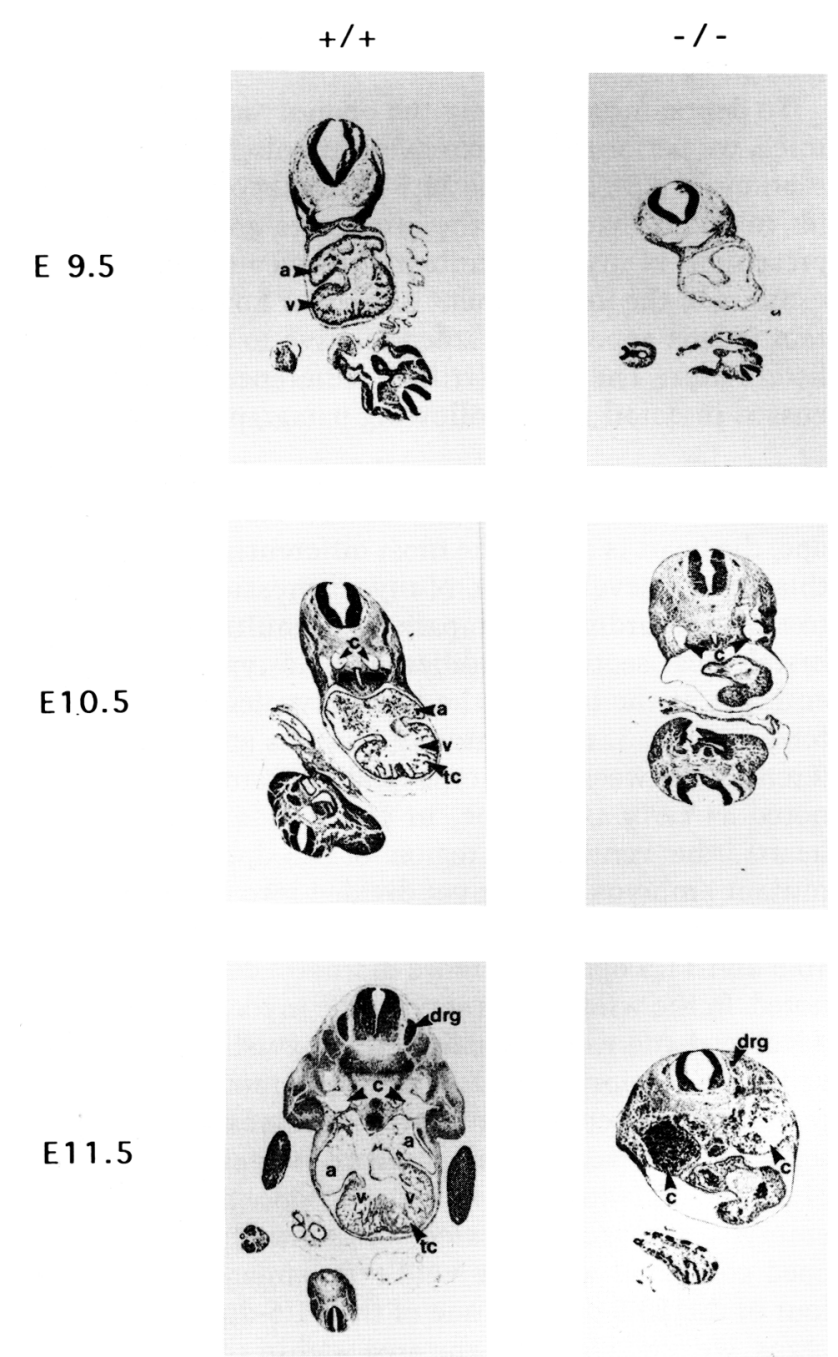

Figure 3. Histological analysis of hearts derived from $\mathrm{N}-m y c$ wild-type and homozygous mutant embryos. Transversal sections through the heart of 9.5-dpc (E9.5, top), 10.5-dpc (E10.5, middle), and 11.5-dpc (E11.5, bottom) wild-type $(+/+$, left $)$ and homozygous $\mathrm{N}-m y c$ mutant $(-1-$, right $)$ embryos are shown. (a) Atria; (c) anterior cardinal vein; (drg) dorsal root ganglia $;$ (tc) trabeculae carneae; $(\mathrm{v})$ ventricles. The magnifications are $24 \times$ for the 9.5 -dpc embryos and $15 \times$ for the $10.5-$ and $11.5-\mathrm{dpc}$ embryos.

found in the brain, cranial ganglia, and spinal ganglia; expression is also found in the neural crest-derived maxillary and mandibular processes (Kato et al. 1991). The earliest differences observed for the mutant embryos were seen at $9.5 \mathrm{dpc}$. Size reduction of the spinal and cranial ganglia (most notably the trigeminal $\mathrm{V}$ and the acoustico-facialis ganglia) was most obvious in 10.5- and 11.5-dpc mutant embryos (Fig. 4A-C). In addition, the trigeminal, acoustico-facialis, and dorsal root ganglia had a less dense cellularity in some $\mathrm{N}-\mathrm{myc}^{-1-}$ embryos than in wild-type embryos. Irregularity and decreased cellularity in the neural ectoderm of the telencephalon and myelencephalon also was observed in some mutant embryos (Fig. 4A).

The cranial and the spinal ganglia contain the sensory neuron cell bodies. Therefore, we looked for perturbation of axon formation by staining sections with antibodies against neurofilament, N-CAM, and another neural-specific marker, mAb3A10 (Furley et al. 1990). By this method of analysis, axon extension and fasciculation appeared normal (data not shown). N-myc is expressed in the developing neural retina and lens (Hirning et al. 1991). However, invagination of the optic vesicles and the lens vesicles appeared normal, though perhaps slightly delayed, in the mutant embryos.

Other organs During renal development, the N-myc gene is highly expressed in the mesonephric tubular cells just derived from the conversion of the embryonic mesenchyme to epithelium (Mugrauer et al. 1988; Kato et al. 1991). At all stages analyzed $(9.5,10.5$, and $11.5 \mathrm{dpc})$ mesonephric tubules of mutant embryos appeared morphologically normal. However, the number of tubules observed in the $\mathrm{N}-\mathrm{myc}^{-1-}$ embryos was reduced compared with that of their wild-type and heterozygous littermates (Fig. 5). It should be emphasized, however, that these kidney defects are unlikely to be associated with the death of homozygous N-myc mutant embryos, as embryogenisis proceeds well in mutants of both mice and humans that lack kidneys (Gluecksohn-Schoenheimer 1945; Phillips 1970).

$\mathrm{N}$-myc expression has also been found in other sites at 9.5-12.5 dpc, including mandibular and maxillary processes, sclerotome, and the digestive tract (Kato et al. 1991). However, histological analyses revealed no major abnormalities in these tissues in $\mathrm{N}-m y c$ homozygous mutant mice.

\section{Discussion}

Lack of $N$-myc function results in embryonic lethality

A recessive null mutation at the $\mathrm{N}$-myc locus results in lethality during embryonic development of homozygotes. Based on the early onset and abundance of $\mathrm{N}-\mathrm{myc}$ expression during gastrulation (Downs et al. 1989), it may have been predicted that $\mathrm{N}-\mathrm{myc}^{-1-}$ mice would die very early in development. Moreover, the apparent role of $\mathrm{N}-\mathrm{myc}$ in proliferation or in the cell cycle also would suggest a possible cell-lethal phenotype (Morrow et al. 1992; Rustgi et al. 1991; Wagner and Green 1991). However, our data clearly indicate that homozygous mutant embryos develop relatively normally until $9.5 \mathrm{dpc}$ and do not die until 10.5-12.5 dpc of gestation, a time after which much of the abundant early $\mathrm{N}-$ myc expression has occurred. Histological analyses showed that major organ systems are present in developing embryos but that several organs such as the heart, the CNS, and the kidney appeared developmentally retarded. Therefore, lack of the $\mathrm{N}$-myc product does not affect the initial stages of organogenisis but does seem to interfere with the normal development of some organs apparently by perturbing normal cellular proliferation and/or more advanced 

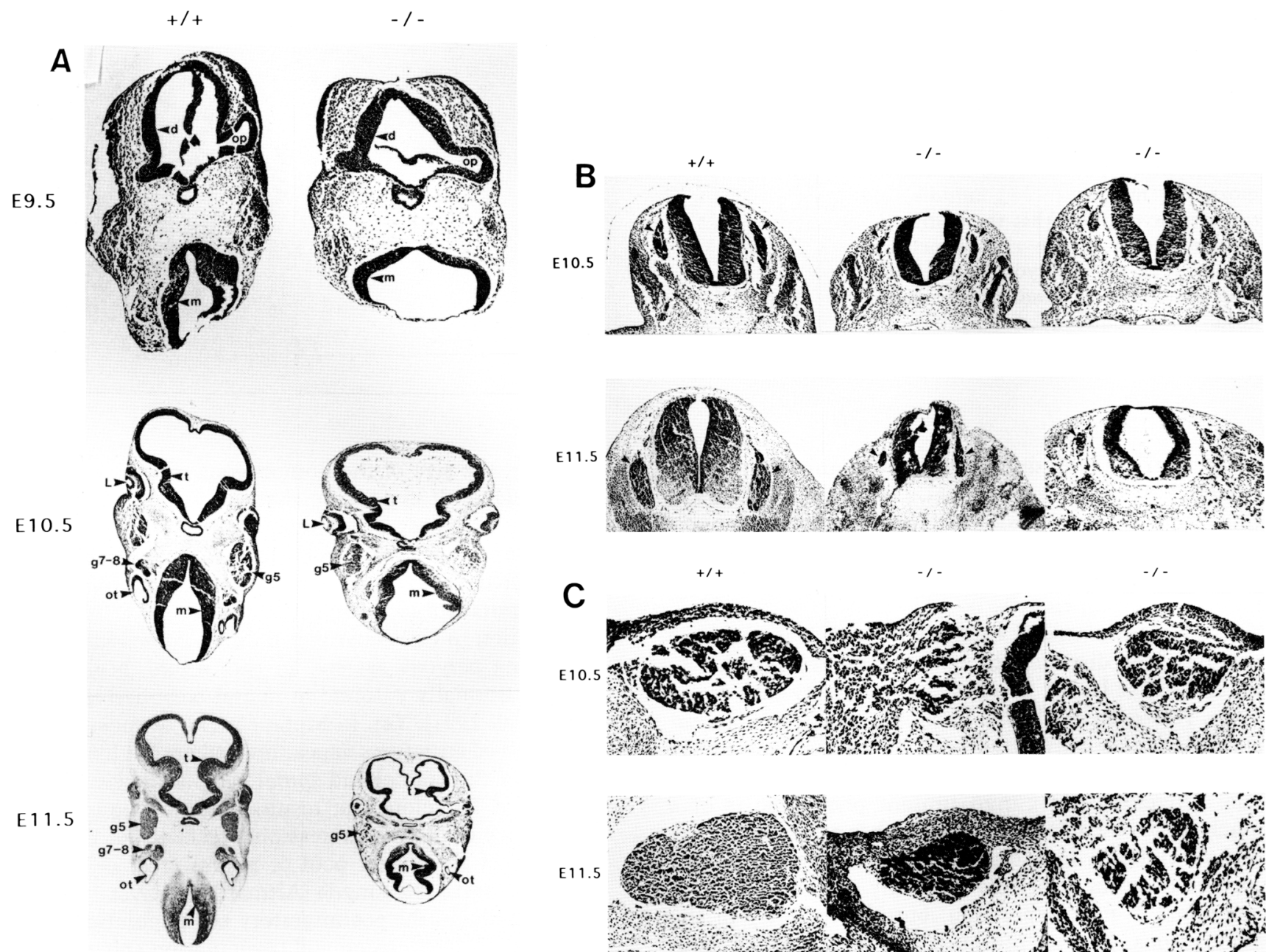

Figure 4. Histological analysis of CNS from wild-type and N-myc $c^{-1-}$ embryos. $(A)$ Transversal sections through the brain at the level of the trigeminal ganglia of 9.5- (E9.5), 10.5- (E10.5), and 11.5- (E11.5) wild-type $(+/+$, left) and homozygous mutant $(-/-$, right) embryos. Note that the homozygous mutant embryo at $11.5 \mathrm{dpc}$ was reduced in size and cellularity compared with the normal control. The magnifications are $55 \times$ for the 9.5-dpc embryos and $22 \times$ for the 10.5- and 11.5-dpc embryos. (d) Diencephalon; (g5) trigeminal ganglia; (g7-8) acoustico-facialis ganglia; (L) lens invagination; $(\mathrm{m})$ myelencephalon; (op) optic vesicle; (ot) otic vesicle; $(\mathrm{t})$ telencephalon. $(B)$ Transversal sections at the level of the heart to show the dorsal root ganglia of 10.5-dpc (E10.5) and 11.5-dpc (E11.5) wild-type $(+1+$, left $)$ and two homozygous mutant $(-1-$, middle and right $)$ embryos. Magnification, $42 \times .(C)$ High magnification $(84 \times)$ of trigeminal ganglia from transversal brain sections of wild-type $(+1+$, left $)$ and two homozygous mutant $(-1-$, middle and right $)$ embryos.

stages of differentiation. This interpretation is supported by the finding that ES cells that lack a functional N-myc gene proliferate normally and are able to contribute to a variety of somatic tissues in chimeric embryos and adults (Sewal et al. 1991; B.A. Malynn, J. Charron, and F.W. Alt, unpubl.).

The embryonic lethality displayed by homozygous $\mathrm{N}$-myc mutant animals contrasts with the phenotype of mice that have targeted mutations of the tyrosine kinase class of oncogenes. Although the products of these genes have been implicated in cell proliferation, homozygous mutant animals displayed a surprisingly limited phenotype (Schwartzberg et al. 1991; Soriano et al. 1991; Tybulewicz et al. 1991; Molina et al. 1992). One proposed explanation for the lack of a major phenotype associated with these mutations is the functional redundancy between different members of this family of related proteins (Soriano et al.1991). N-myc belongs to a gene family whose members may well have overlapping activity (for review, see Zimmerman and Alt 1990). However, the more severe phenotype of the homoygous $\mathrm{N}$-myc mutation indicates that it plays a unique role in more tissues and earlier than most members of the tyrosine kinase class of oncogenes. In general, N-myc and c-myc are coexpressed in embryos during gastrulation (Downs et al. 1989). The onset of developmental defects in homozygous $\mathrm{N}-m y c$ mutants is manifest only when the expression patterns of $\mathrm{N}-\mathrm{myc}$ and $\mathrm{c}-\mathrm{myc}$ start to be differen- 
Figure 5. Histological analysis of kidney from wild type and $\mathrm{N}-\mathrm{myc}^{-1-}$ embryos. Transversal sections through the kidney of 10.5-dpc wild-type $(+1+$, left $)$ and two homozygous mutant $1-/-$, middle and right) embryos. Note that the $\mathrm{N}-\mathrm{myc}^{-1-}$ embryo shown in the right panel was smaller than the embryos shown in the other panels. (mst) Mesonephric tubules; (msd) mesonephric duct. Magnification, $38 \times$.
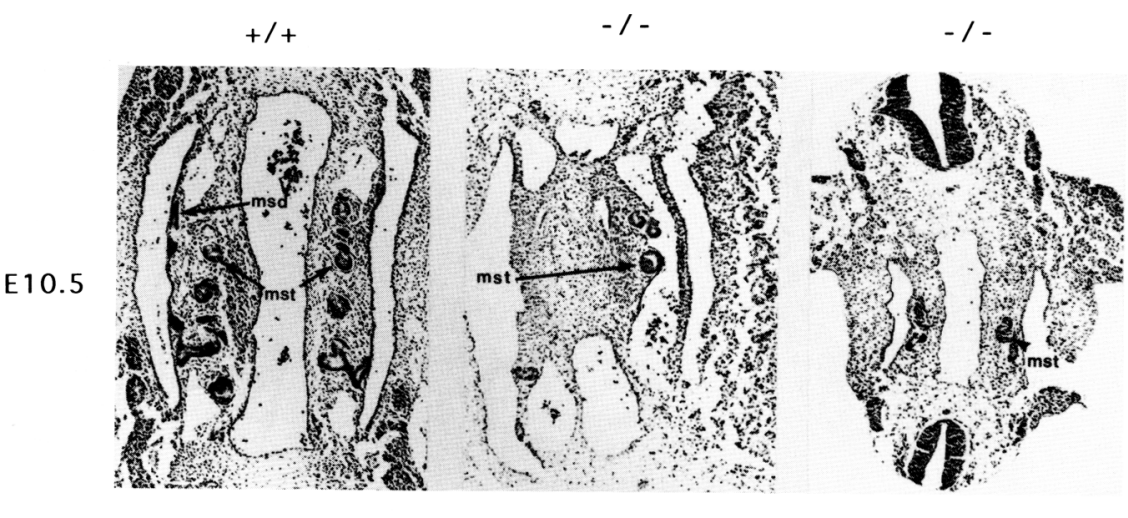

tially restricted to different tissue components $(\mathrm{Mu}-$ grauer et al. 1988; Hirning et al. 1991; Kato et al. 1991); thus, coincident expression of $\mathrm{N}-\mathrm{myc}$ and c-myc (or possibly L-myc) may explain (1) why mutant embryos survive until mid-gestation and (2) the lack of a major phenotype in certain tissues.

$\mathrm{N}$-myc is the second example of a nuclear oncogene that has been disrupted by homologous recombination. Embryos that lack a functional c-myb gene also die in utero. However, the lethal phenotype of c-myb mutant embryos is not manifested until $15 \mathrm{dpc}$ and apparently results primarily from a block in adult-type erythropoiesis. Therefore, the c-myb mutant phenotype is of a much more restricted nature than that exhibited by the $\mathrm{N}$-myc mutants. In addition, embryonic erythropoiesis appears to occur relatively normally in the absence of functional $\mathrm{N}-m y c$ expression, but the lethality of the homozygous $\mathrm{N}-m y c$ mutation at mid-gestation precludes analysis of $\mathrm{N}-m y c$ function in adult type erythropoiesis.

The $\mathrm{N}-\mathrm{myc}$ protein belongs to a class of transcription factors that contain helix-loop-helix and/or leucine zipper motifs; some of these proteins have been implicated in the control of cell determination (Lüscher and Eisenman 1990/. Our studies provide the first direct demonstration of a critical role for such proteins in the developing mammalian embryo. In addition, a number of genes encoding other putative transcription factors of the homeo box class of proteins have been mutated by gene targeting (Chisaka and Capecchi 1991; Joyner et al. 1991; Lufkin et al. 1991; LeMouellic et al. 1992). The resulting mutants also exhibited restricted phenotypic abnormalities compared with those observed for N-myc mutants.

\section{Specific defects associated with the N-myc null Mutation}

All of the defects documented in N-myc mutant embryos occur in tissues that normally express the $\mathrm{N}-m y c$ gene. One of the more pronounced phenotypes observed in mutant embryos was a reduction in size that apparently correlates with a decrease in total cell number.
However, the size of the homozygous mutant embryos varied widely. It is possible that the variability in phenotype may reflect a difference of expressivity of the $\mathrm{N}$-myc mutation owing to the genetic heterogeneity of the outbred background into which the homozygous $\mathrm{N}$-myc mutant mice were generated.

Reduction in cell density or number is obvious in the developing nervous system. In this regard, N-myc expression normally is found in neural crest-derived cells (Kato et al. 1991). Yet, in mutant embryos most neural crest-derived structures appear normal except for the reduction of the cranial and spinal ganglia in size and/or cellularity. Therefore, our results could be explained if the absence of $\mathrm{N}-m y c$ expression affects either the proliferation of the initial pool of neural crest cells that migrate to form the ganglia (Altman and Bayer 1982) or the expansion of the postmigratory cell population. Furthermore, axon extension and fasciculation appears normal in the mutant embryos, which suggests that the absence of N-myc does not prevent the differentiation of neural crest cells into neurons, at least at this developmental stage.

$\mathrm{N}$-myc is also expressed in the mesonephric tubules that are derived by the conversion of the mesonephric mesenchyme into a polarized epithelium (Mugrauer et al. 1988; Ekblom 1989; Kato et al. 1991). This conversion in the mesonephros, which is a transient structure, is similar to the conversion that will occur later during kidney development (derived from the metanephros, around embryonic day 12). It is known that in the kidney, the conversion of the mesenchyme into epithelium of the kidney tubules occurs in response to an inductive signal from the ureter epithelium (Grobstein 1956). In $\mathrm{N}-\mathrm{myc}^{-1-}$ embryos, we observe the presence of mesonephric tubules in the mesonephros, which suggests that the lack of $\mathrm{N}$-myc expression does not affect the conversion of the mesonephric mesenchyme into epithelium. However, the number of mesonephric tubules formed is reduced, suggesting that $\mathrm{N}-m y c$ expression may be required for the appropriate proliferation of the induced mesenchyme in response to the inductive signals. Mice homozygous for a mutation that leads to impaired expression of the normal $\mathrm{N}-\mathrm{myc}$ product show an underdevelopment of the lung airway epithelium. It was pro- 
posed that $\mathrm{N}-m y c$ is required for the proliferation of the lung epithelium in response to a local inductive signal emanating from the lung mesenchyme (Bernelot-Moens et al. 1992). In the homozygous mutant $\mathrm{N}-m y c$ embryos of our studies, the development of the lung appears normal until at least $11.5 \mathrm{dpc}$. Therefore, although $\mathrm{N}-\mathrm{myc}$ may play vital roles in differentiation of other organs later in development, the early onset of lethality during organogenisis in homozygous null mutants precludes investigation of such functions.

Mice homozygous for the N-myc mutation most likely die from a major defect of the heart. Lack of functional $\mathrm{N}$-myc expression results either in embryos that do not form a heart containing four well-developed chambers or in embryos in which the heart contains the atria and ventricles but underdeveloped valvular and septal tissues as well as trabecula carnea. During heart development, interactions between the cardiac endothelium and the myocardium lead to an epithelium-mesenchymal transformation that generates the anlagen of valvular and septal tissues and the trabeculation of the ventricles (Zak 1984). The absence of any valvular or septal tissues in some embryos suggests that lack of $\mathrm{N}-m y c$ protein may impact in some way upon this differentiation process. Previous studies indicated that the epithelium-mesenchymal transformation depends on a developmentally regulated signal expressed by the associated myocardium (Mjaatvedt et al. 1991 and references therein). Because the $\mathrm{N}-m y c$ gene is normally expressed in the myocardium (Kato et al. 1991), our findings suggest that lack of $\mathrm{N}$-myc expression may interfere with the production of this signal.

\section{Possible function of the $\mathrm{N}$-myc protein}

Our analyses of developmental defects in $\mathrm{N}$-myc mutant embryos have not clearly defined a function for the $\mathrm{N}$-myc protein; however, a number of significant general observations can be made. First, it is clear that the $\mathrm{N}-m y c$ defect is manifested in a variety of different tissues and organs, indicating that this protein has a rather generalized function in development. In addition, most of the noted defects were more consistent with a reduction in cell number or density than with a block in differentiation per se. One possible interpretation of our findings is that $\mathrm{N}-m y c$ expression may be required to expand specific pools of precursor cells by promoting their growth, inhibiting their death, and/or preventing their terminal differentiation. It has been shown that constitutive expression of c-myc can inhibit differentiation of cultured cell lines (Theile et al. 1985; Coppola and Cole 1986; Denis et al. 1987; Freytag 1988; Larcher et al. 1991). In addition, it is notable that prelymphocytespecific growth factor, Il-7, induces $\mathrm{N}-m y c$ in pre-B cells while also inducing proliferation, but not differentiation. In this context, defects associated with the lack of $\mathrm{N}$-myc expression might be attributed to the lack of a sufficient quantity of particular stem cells. Recently, it has been suggested that $\mathrm{N}-m y c / \mathrm{Rb}$ interactions may be involved in the control of cell proliferation and that $\mathrm{N}$-myc expression may prevent entry into a distinct predifferentiation state in $G_{0} / G_{1}$ that is a prerequisite for terminal differentiation (Wagner and Green 1991). Thus, for certain cell types, $\mathrm{N}$-myc may serve as a molecular switch, directing cells to a pathway that can lead either to continued proliferation or to terminal differentiation.

\section{Materials and methods}

Southern blot analysis

Tail and embryo DNA was prepared as described previously (Hogan et al. 1986). Purified DNA was digested with the indicated restriction endonuclease, fractionated by electrophoresis through $0.8 \%$ agarose gels, blotted onto $\mathrm{N}$-Hybond membrane (Amersham), and hybridized to the $5^{\prime} \mathrm{N}$-myc EcoRI-BamHI probe described in Charron et al. (1990). Blots were washed with $0.1 \times$ SSC and $0.1 \%$ SDS at $65^{\circ} \mathrm{C}$.

\section{Northern blot analysis}

Total RNA was prepared from 10.5-dpc embryos as described (Auffray and Rougeon 1980), and Northern blotting was performed according to Maniatis et al. (1989). A 330-bp XhoI$B s s H I$ genomic fragment and a $2.1-\mathrm{kb}$ ClaI-EcoRI genomic fragment were used as second and third exon probes, respectively (DePinho et al. 1986). The human $\beta$-actin probe was a 2.2-kb cDNA fragment (Gunning et al. 1983).

\section{Generation of germ-line chimeras}

Embryo manipulations were carried out as described (Schwartzberg et al. 1989). Ten to twelve ES cells from the N-myc mutant cell lines were injected per blastocyst, which were derived from C57BL/ 6 or MF-1 mice. Injected blastocysts were cultured in ES cell medium for 1-2 hr before transfer of 6-10 embryos to one uterine horn of one pseudopregnant female mouse. Chimeric pups were identified by eye pigmentation when MF-1 blastocysts were used or by coat color chimerism when C57BL/ 6 blastocysts were injected. Chimeric males were bred to MF-1 or C57BL/ 6 females to test for germ-line transmission of the dominant agouti coat color marker. Transmission of the mutated allele was detected by Southern blot analysis of tail DNA from Fl offspring with agouti coat color.

\section{Histological analysis}

Embryos were dissected out of the visceral yolk sac and fixed for $16 \mathrm{hr}$ in $4 \%$ paraformaldehyde, dehydrated in graded alcohols and xylenes, and embedded in paraffin as described (Wilkinson and Green 1990). Sections of $6 \mu \mathrm{m}$ thickness were stained with Harris hematoxylin and eosin. Black-and-white micrographs were taken with a Nikon Optiphot-2 microscope, a Nikon FXDX photomicrographic system, and Kodak technical pan film.

\section{Acknowledgments}

This work was supported by the Howard Hughes Medical Institute, by U.S. Public Health Service grants CA23767 to F.W.A. and P01-CA23767 to S.P.G. and F.W.A., and by a Cancer Research Society grant of Canada to J.C. J.C. is currenty a scholar from the Canadian Medical Research Council (MRC); B.A.M. is 
an arthritis investigator and a special fellow of the Leukemia Society of America, and L.J. is a scholar from the Canadian MRC and the Cancer Research Society, Inc. We give special thanks to Jane Dodd for her help with the axon stains and to Larysa Pevny for her help with the in vitro erythrocyte differentiation assay. We also thank R. DePinho, P. Ekblom, M. Bernfield, and G. Yancopoulos for critically reading the manuscript.

The publication costs of this article were defrayed in part by payment of page charges. This article must therefore be hereby marked "advertisement" in accordance with 18 USC section 1734 solely to indicate this fact.

\section{References}

Alex, R., O. Sozeri, S. Meyer, and R. Dildrop. 1992. Determination of the DNA sequence recognized by the bHLH-zip domain of the N-myc protein. Nucleic Acids Res. 20: 22572263.

Alt, F.W., R. DePinho, K. Zimmerman, E. Legouy, K. Hatton, P. Ferrier, A. Tesfaye, G. Yancopoulos, and P. Nisen. 1986. The human myc gene family. Cold Spring Harbor Symp. Quant. Biol. 51: 931-941.

Altman, J. and S. Bayer. 1982. Development of the cranial nerve ganglia and related nuclei in the rat. Springer-Verlag, New York.

Auffray, C. and F. Rougeon. 1980. Purification of mouse immunoglobulin heavy-chain messenger RNAs from total myeloma tumor RNA. Eur. /. Biochem. 107: 303-314.

Bernelot-Moens, C., A.B. Auerbach, R.A. Conlon, A.L. Joyner, and J. Rossant. 1992. A targeted mutation reveals a role for $\mathrm{N}$-myc in branching morphogenesis in the embryonic mouse lung. Genes \& Dev. 6: 691-704.

Blackwell, T.K., L. Kretzner, E.M. Blackwood, R.N. Eisenman, and H. Weintraub. 1990. Sequence-specific DNA-binding by the c-myc protein. Science 250: 1149-1151.

Blackwood, E.M. and R.N. Eisenman. 1991. Max: A helix-loophelix zipper protein that forms a sequence-specific DNAbinding complex with Myc. Science 251: 1211-1217.

Caudy, M., H. Vaessin, M. Brand, R. Tuma, L.Y. Jan, and Y.N. Jan. 1988. Daughterless, a Drosophila gene essential for both neurogenesis and sex determination, has sequence similarities to myc and the achaete-scute complex. Cell 55: 10611067.

Cavalieri, F. and M. Goldfarb. 1988. N-myc proto-oncogene expression can induce DNA replication in Balb/c 3T3 fibroblasts. Oncogene 2: 289-291.

Charron, J., B.A. Malynn, E.J. Robertson, S.P. Goff, and F.W. Alt. 1990. High-frequency disruption of the N-myc gene in embryonic stem and pre-B cell lines by homologous recombination. Mol. Cell. Biol. 10: 1799-1804.

Chisaka, O. and M.R. Capecchi. 1991. Regionally restricted developmental defects resulting from targeted disruption of the mouse homeobox gene hox-1.5. Nature 350: 473-479.

Coppola, J. and M.D. Cole. 1986. Constitutive c-myc oncogene expression blocks mouse erythroleukemia cell differentiation but not commitment. Nature 320: 760-763.

Denis, N., M.P. Blanc, M.P. Leibovitch, and N. Nicolaiew. 1987. c-myc oncogene expression inhibits the initiation of myogenic differentiation. Exp. Cell. Res. 172: 212-217.

DePinho, R.A., E. Legouy, L.B. Feldman, N.E. Kohl, G.D. Yancopoulos, and F.W. Alt. 1986. Structure and expression of the murine N-myc gene. Proc. Natl. Acad. Sci. 83: 1827-1831.

Downs, K.M., G.R. Martin, and J.M. Bishop. 1989. Contrasting patterns of $m y c$ and $N-m y c$ expression during gastrulation of the mouse embryo. Genes \& Dev. 3: $860-869$.

Ekblom, P. 1989. Developmentally regulated conversion of mesenchyme to epithelium. FASEB I. 3: 2141-2150.

Freytag, S.O. 1988. Enforced expression of the c-myc oncogene inhibits cell differentiation by precluding entry into a distinct predifferentiation stage in G0/Gl. Mol. Cell. Biol. 8: $1614-1624$.

Furley, A.J., S.B. Morton, D. Manalo, D. Karagogeos, J. Dodd, and T.M. Jessel. 1990. The axonal glycoprotein TAG-1 is an immunoglobulin superfamily member with neurite outgrowth-promoting activity. Cell 61: 157-170.

Gluecksohn-Schoenheimer, S. 1945. The embryonic development of mutants of the Sd-strain in mice. Genetics 30: 2938.

Grobstein, C. 1956. Trans-filter induction of tubules in mouse metanephrogenic mesenchyme. Exp. Cell. Res. 10: 424-440.

Gunning, P., P. Pomte, H. Okayama, J. Engel, H. Blau, and L. Kedes. 1983. Isolation and characterization of full-length cDNA clones for human alpha-, beta-, and gamma-actin mRNAs: Skeletal but not cytoplasmic actins have an aminoterminal cysteine that is subsequently removed. Mol. Cell. Biol. 3: 787-795.

Halazonetis, T.D. and A.N. Kandil. 1991. Determination of the c-myc DNA-binding site. Proc. Natl. Acad. Sci. 88: 61626166.

Hirning, U., P. Schmid, W.A. Schulz, G. Rettenberger, and H. Hameister. 1991. A comparative analysis of N-myc and $\mathrm{c}-\mathrm{myc}$ expression and cellular proliferation in mouse organogenesis. Mech. Dev. 33: 119-125.

Hogan, B., F. Constantini, and E. Lacy. 1986. Manipulation of the mouse embryo: A laboratory manual. Cold Spring Harbor Laboratory, Cold Spring Harbor, New York.

Joyner, A.L., K. Herrup, B.A. Auerbach, C.A. Davis, and J. Rossant. 1991. Subtle cerebellar phenotype in mice homozygous for a targeted deletion of the En-2 homeobox. Science 251: 1239-1243.

Kato, K., A. Kanamori, Y. Wakamatsu, S. Sawai, and H. Kondos. 1991. Tissue distribution of $\mathrm{N}$-myc expression in the early organogenesis period of the mouse embryo. Dev. Growth Differ. 33: 29-36.

Kerkhoff, E., K. Bister, and K.H. Klempnauer. 1991. Sequencespecific DNA binding by myc proteins. Proc. Natl. Acad. Sci. 88: 4323-4327.

Larcher, J.C., J.L. Vayssiere, L. Lossouarn, F. Gros, and B. Croizat. 1991. Regulation of c- and N-myc expression during induced differentiation of murine neuroblastoma cells. Oncogene 6: 633-638.

LeMouellic, H., Y. Lallemand, and P. Brulet. 1992. Homeosis in the mouse induced by a null mutation in the Hox-3.1 gene. Cell 69: 251-264.

Lufkin, T., A. Dierich, M. LeMeur, M. Mark, and P. Chambon. 1991. Disruption of the Hox-1.6 homeobox gene results in defects in a region corresponding to its rostal domain of expression. Cell 66: 1105-1119.

Lüscher, B. and R.N. Eisenman. 1990. New light on Myc and Myb. Part I. Myc. Genes \& Dev. 4: 2025-2035.

Ma, A., T. Moroy, R. Collum, H. Weintraub, F.W. Alt, and T.K. Blackwell. 1992. DNA binding by $\mathrm{N}-$ and L-Myc proteins. Oncogene (in press).

Maniatis, T., S. Fritsch, and J. Sambrook. 1989. Molecular cloning: A laboratory manual. Cold Spring Harbor Laboratory Press, Cold Spring Harbor, New York.

Mjaatvedt, C.H., E.L. Krug, and R.R. Markwald. 1991. An antiserum (ES1) against a particulate form of extracellular matrix blocks the transition of cardiac endothelium into mesenchyme in culture. Dev. Biol. 145: 219-230. 
Molina, T.J., K. Kishihara, D.P. Siderovski, W. van Ewijk, A. Narendran, E. Timms, A. Wakeham, C.J. Paige, K.U. Hartmann, A. Veillette, D. Davidson, and T.W. Mak. 1992. Profound block in thymocyte development in mice lacking p56lck. Nature 357: 161-164.

Morrow, M.A., G. Lee, S. Gillis, G. Yancopoulos, and F.W. Alt. 1992. Interleukin-7 induces $\mathrm{N}-m y c$ and $c-m y c$ expression in normal precursor B lymphocytes. Genes \& Dev. 6: 61-70.

Mucenski, M.L., K. McLaine, A.B. Kier, S.H. Swerdlow, C.M. Shreiner, T.A. Miller, D.W. Pietryga, W.J. Scott, and S.S. Potter. 1991. A functional c-myb gene is required for normal murine fetal hematopoieses. Cell 65: 677-689.

Mugrauer, G., F.W. Alt, and P. Ekblom. 1988. N-myc protooncogene expression during organogenesis in the developing mouse as revealed by in situ hybridization. $I$. Cell. Biol. 107: 1325-1335.

Olso, E.N. 1990. MyoD family: A paradigm for development. Genes \& Dev. 4: 1445-1461.

Phillips, R.J.S. 1970. Mouse Newslett. 42: 26.

Prendergast, G.C. and E.B. Ziff. 1991. Methylation-sensitive sequence-specific DNA-binding by the c-myc basic region. Science 251: 186-189.

. 1992. A new bind for Myc. Trends Genet. 8: 91-96.

Prendergast, G.C., D. Lawe, and E.B. Ziff. 1991. Association of Myn, the murine homolog of Max, with c-Myc stimulates methylation-sensitive DNA binding and Ras cotransformation. Cell 65: 395-407.

Rustgi, A.K., N. Dyson, and R. Bernards. 1991. Amino-terminal domain of $\mathrm{c}$-myc proteins mediate binding to the retinoblastoma gene product. Nature 352: 541-544.

Schwartzberg, P.L., S.P. Goff, and E.J. Robertson. 1989. Germline transmission of a $\mathrm{c}$-abl mutation produced by targeted gene disruption in ES cells. Science 246: 799-803.

Schwartzberg, P.L., A.M. Stall, J.D. Hardin, K.S. Bowdish, T. Humaran, S. Boast, M.L. Harbison, E.J. Robertson, and S.P. Goff. 1991. Mice homozygous for the ablml mutation show poor viability and depletion of selected $B$ and $T$ cell populations. Cell 65: 1165-1175.

Sewal, S., A. Shimono, K. Hanaoka, and H. Kondoh. 1991. Embryonic lethality resulting from disruption of both N-myc alleles in mouse zygotes. New Biol. 3: 861-869.

Soriano, P., C. Montgomery, R. Geske, and A. Bradley. 1991. Targeted disruption of the c-src proto-oncogene leads to osteopetrosis. Cell 64: 693-702.

Theile, C.J., C.P. Reynolds, and M.A. Israel. 1985. Decreased expression of $\mathrm{N}$-myc precedes retinoic acid-induced morphological differentiation of human neuroblastoma. Nature 313: 404-406.

Thisse, B., C. Stoetzel, C. Gorastize-Thisse, and F. PerrinSchmitt. 1988. Sequence of the twist gene and nuclear localization of its protein in endomesodermal cells of early Drosophila embryos. EMBO I. 7: 2175-2184.

Tybulewicz, V.L., P.K. Jackson, R.T. Bronson, and R.C. Mulligan. 1991. Neonatal lethality and lymphopenia in mice with a homozygous disruption of the c-abl proto-oncogene. Cell 65: 1153-1163.

Villares, R. and C.V. Cabrera. 1987. The achaete-scute gene complex of D. melanogaster: Conserved domains in a subset of genes required for neurogenesis and their homology to myc. Cell 50: 415-424.

Wagner, S. and M.R. Green. 1991. A transcriptional tryst. Nature 352: 189-190.

Weintraub, S.J., C.A. Prater, and D.C. Dean. 1992. Retinoblastoma protein switches the E2F site from positive to negative element. Nature 358: 259-261.

Wilkinson, D.G. and J. Green. 1990. In situ hybridization and the three-dimensional reconstitution of serial sections. In Postimplantation mammalian embryos: $A$ practical approach (ed. A.J. Copp and D.L. Cockroft), pp. 155-172. IRL Press, Oxford, England.

Wong, P.M.C., S.W. Chung, D.H.K. Chui, and C.J. Eaves. 1986. Properties of the earliest clonogenic homopoietic precursors to appear in the developing murine yolk sac. Proc. Natl. Acad. Sci. 83: 3851-3854.

Wong, P.M.C., S.W. Shung, S. Reicheld, and D.H.K. Chul. 1986. Hemoglobin switching during murine embryonic development: Evidence for two populations of embryonic erythropoietic progenitor cells. Blood 67: 716-721.

Zak, R. 1984. Growth of the heart in health and disease. Raven Press, New York.

Zimmerman, K. and F.W. Alt. 1990. Expression and function of myc family genes. Crit. Rev. Oncogenes 2: 75-95. 


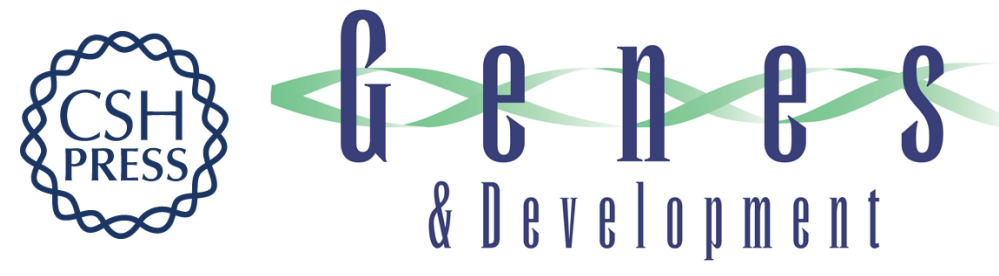

\section{Embryonic lethality in mice homozygous for a targeted disruption of the $\mathrm{N}$-myc gene.}

J Charron, B A Malynn, P Fisher, et al.

Genes Dev. 1992, 6:

Access the most recent version at doi:10.1101/gad.6.12a.2248

References This article cites 53 articles, 20 of which can be accessed free at:

http://genesdev.cshlp.org/content/6/12a/2248.full.html\#ref-list-1

License

Email Alerting

Service

Receive free email alerts when new articles cite this article - sign up in the box at the top right corner of the article or click here.

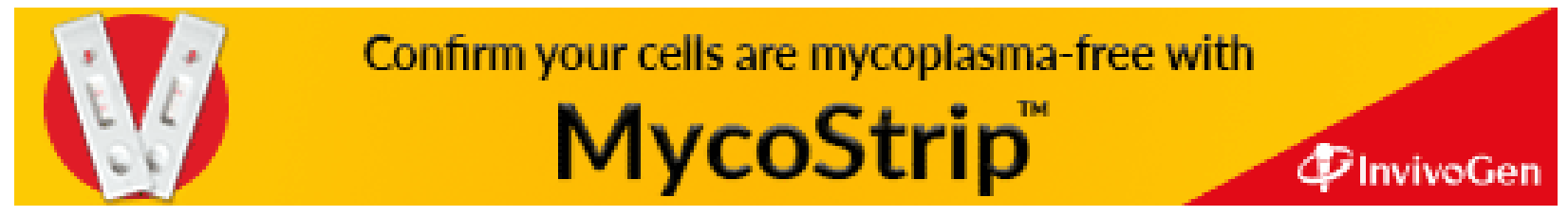

